\title{
Is Cash Waqf Linked Sukuk (CWLS) Less Than Ideal According to Islamic Laws?
}

\author{
AKHMAD HAFANDI ${ }^{1}$, PUJ HANDAYATI ${ }^{2}$ \\ ${ }^{1}$ Post Graduate Program of Islamic Studies, STATE ISLAMIC UNIVERSITY OF SUNAN AMPEL, INDONESIA. \\ E-mail: ahafandi@ymail.com \\ ${ }^{2}$ Faculty of Economics, UNIVERSITAS NEGERI MALANG, INDONESIA. E-mail: puji.handayati.fe@um.ac.id
}

\begin{abstract}
As a step to promote public interest in conducting cash waqf, the government launched a program called the National Money Waqf Movement (GNWU) which also introduced Cash Waqf Linked Sukuk (CWLS) Retail Series SWR001 which is a development of the CWLS (SW Series). Both are developments of the Money Waqf and Sukuk (State Sukuk) which have been regulated in the DSN-MUI Fatwa No. 131/DSN-MUI/X/2019. Law No. 41 of 2004, concerning Waqf, and Law No. 19 of 2008, concerning State Sharia Securities (SBSN). CWLS is a form of social investment in Indonesia where the cash waqf is received by the Indonesian Waqf Board as Nazhir through a Sharia Financial Institution as a Cash Waqf Recipient (LKSPWU). It will be managed and placed on the State Sukuk or SBSN instrument and the proceeds of its development are used to finance various economic, social and religious activities. Nonetheless, this CWLS model is perceived to be less than ideal by some parties. This study adopted a qualitative method using using library research approach. The data were collected through analysing literature papers, documentation and conducting an interview. Descriptive-analysis used to compare the statutory provisions, fatwas of MUI, and figh rules with the implementation of CWLS. The findings in this study indicate that CWLS is an appropriate with Indonesian context and Islamic principles.
\end{abstract}

Keywords: Waqf; Cash; CWLS; Islamic Laws.

JEL Classification: E40, E42, P50

Received: June 4, 2021

Accepted: September 29, 2021 


\title{
Es Cash Waqf Linked Sukuk (CWLS) menos que Ideal según las leyes islámicas?
}

\author{
AKHMAD HAFANDI ${ }^{1}$, PUJI HANDAYATI ${ }^{2}$ \\ ${ }^{1}$ Post Graduate Program of Islamic Studies, STATE ISLAMIC UNIVERSITY OF SUNAN AMPEL, INDONESIA. \\ E-mail: ahafandi@ymail.com \\ ${ }^{2}$ Faculty of Economics, UNIVERSITAS NEGERI MALANG, INDONESIA. E-mail: puji.handayati.fe@um.ac.id
}

\begin{abstract}
RESUMEN
Como un paso para promover el interés público en la realización de waqf en efectivo, el gobierno lanzó un programa llamado National Money Waqf Movement (GNWU) que también introdujo Cash Waqf Linked Sukuk (CWLS) Retail Series SWR001, que es un desarrollo de CWLS (SW Series). Ambos son desarrollos de Money Waqf y Sukuk (State Sukuk) que han sido regulados en DSN-MUI Fatwa No. 131 / DSN-MUI / X / 2019. Ley No. 41 de 2004, relativa al Waqf, y la Ley No. 19 de 2008, relativo a State Sharia Securities (SBSN). CWLS es una forma de inversión social en Indonesia, donde el waqf en efectivo es recibido por la Junta de Waqf de Indonesia como Nazhir a través de una Institución Financiera de la Sharia como Beneficiario del Waqf en Efectivo (LKSPWU). Se administrará y se colocará en el instrumento estatal Sukuk o SBSN y el producto de su desarrollo se utilizará para financiar diversas actividades económicas, sociales y religiosas. No obstante, algunas partes perciben este modelo CWLS como menos que ideal. Este estudio adoptó un método cualitativo utilizando un enfoque de investigación bibliotecaria. Los datos se recopilaron mediante el análisis de artículos de literatura, documentación y realización de una entrevista. Análisis descriptivo utilizado para comparar las disposiciones legales, fatwas de MUI y reglas fiqh con la implementación de CWLS. Los hallazgos de este estudio indican que CWLS es apropiado para el contexto indonesio y los principios islámicos.
\end{abstract}

Palabras Clave: Waqf; Efectivo, CWLS; Leyes islámicas.

Clasificación JEL: E40; E42; P50

Recibido: 04 de Junio de 2021

Aceptado: 29 de Septiembre de 2021 


\section{Introduction}

Waqf is one of the good deeds having two dimensions in its applicative form, namely 'ubūdiyah ilāhiyah which means worship to Allah, that is, a spiritual component, and also a social component in the socio-economic field of the Muslim community. Waqf in Islamic law is an imperative part, as it is one of the commendable behaviors recommended in Islam (Ghazali et al., 2019). However, waqf which is a well-known practice among Muslims, especially in Indonesia, is still limited to land and buildings intended for places of worship, health and education, or other social buildings, while at least until 2004 cash waqf was not yet popular because there were still disputes regarding its validity. In fact, cash waqf has the potential to be developed in Indonesia, as with this cash waqf, the scope of its benefits and mobilization will be much wider, practical and more equitable to the community compared to the conventional-traditional waqf model in the form of physical assets (Qurrata et al., 2020; Merlinda et al., 2021).

The development of a new paradigm of waqf in accordance with current developments and has unified the pros and cons of various schools of thought (Abbasi et al., 2019). This law is also a refinement of the previous legislation which is still very limited, because it only regulates immovable waqf objects and their designation is mostly for the purposes of worship, such as mosques, prayer rooms, Islamic boarding schools and burial places (Iman et al., 2020). It is stipulated that waqf assets include movable objects, which is money. However, after more than a decade since the enactment of the law on cash waqf, the development of cash waqf is insufficient (Qurrata et al., 2020). It is evident from the data obtained from the Indonesian Waqf Agency (BWI) which mentions the potential for cash waqf funds of IDR 180 trillion per year, while in 2020 it has only reached IDR 391 billion. In addition, a preliminary study by Prananingtyas and Disemadi (2020) showed that the collection of cash waqf in KSPPS/USPPS has only reached IDR 33.7 billion. These data indicate that there are still fundamental issues that need to be resolved regarding the potential and realization gaps in the collection of cash waqf in this most generous country (Lailatullailia et al., 2021; Zatadini et al., 2019).

As a step to promote public interest in conducting cash waqf, the government launched a program called the National Money Waqf Movement (GNWU) on January 25, 2021 which also introduced Cash Waqf Linked Sukuk (CWLS) Retail Series SWR001 which is a development of the CWLS (SW Series) (Yunita, 2020). It is an innovation of the State Sukuk as regulated in the DSN-MUI Fatwa No. MUI No. 131/DSN-MUI/X/2019, Law no. 41 of 2004 concerning Waqf and Law no. 19 of 2008 concerning State Sharia Securities (SBSN), which had been launched earlier. The issuance of the Retail CWLS series SWR001 is a form of the Government's commitment to support the National Waqf Movement, assisting the development of social investment and the development of productive waqf in Indonesia. Through the Retail CWLS series SWR001, the Government facilitates cash waqf, both temporary and permanent, so that they can place their money waqf in safe and productive investment instruments. CWLS Retail series SWRO01 has a tenor of two years and offers a fixed rate of $5.5 \%$ per annum/coupon, the rewards of which will be channeled to social programs or activities that have social and economic impact on the community. The distribution of rewards will be carried out by a credible Nazhir who is appointed by the Islamic Financial Institution-Recipient of Cash Waqf (LKSPWU) and approved by the Indonesian Waqf Board (BWI) as regulator and supervisor. Maintaining credibility and accountability of the rewards, Nazhir will have to make reports to BWI, Ministry of Religious Affairs, Ministry of Finance, and waqif (buyer of CWLS) (Latief, 2019; Rahmansyah, 2019).

CWLS and Retail CWLS are an innovation of cash waqf as a form of social investment in Indonesia where cash waqf is collected by the Indonesian Waqf Board as Nazhir through Islamic Financial Institutions such as BNI Syariah Bank and Bank Muamalat Indonesia as Cash Waqf Recipients (LKSPWU) (Yasin, 2021). They will be managed and placed on the State Sukuk instrument or SBSN (State Sharia Securities) issued by the Ministry of Finance. To succeed in the development of the Cash waqf linked sukuk, the Ministry of Finance together with Bank Indonesia, the Ministry of Religious Affairs and the Indonesian Waqf Board have drawn up and signed an MoU which regulates policy and 
operational aspects in its development. The government will issue a special series of State Sukuk "SW" which also has special features, including a three-year tenor, non-tradable, payment of benefits at a discount and a fixed rate of return paid periodically. The government will use the profit of the issuance of the SW series State Sukuk to finance the APBN, including to finance the development of public service projects such as the construction of educational infrastructure and religious services (Indra \& Hakim, 2020; Rahayu \& Agustianto, 2020; Nezliani, 2021).

To illustrate, as of October 1, 2020, the total accumulated SBSN issuance since 2008 was IDR $1,538.43$ trillion or $19 \%$ of the total Government Securities (SUN), while the outstanding SBSN as of that date was IDR 931.33 trillion (Ministry of Finance, 2020). From the total outstanding, 46\% or IDR 118.26 trillion of which is used as Project Financing Sukuk to support productive financing, including financing social infrastructure and social programs in the region, exploration of productive waqf in Riau Province, utilization of non-productive land for livestock or plantation with a potential of 420 thousand ha., Waqf of Dompet Dhuafa Gardens and MSME Empowerment, MSME productive waqf by Waqf House (Anggraini et al., 2019)

The arising issue is that when CWLS was introduced, there were some religious and community leaders who believed that CWLS was different from cash waqf that had been regulated in positive law in Indonesia through Law no. 41 of 2004, therefore, it had been recommended not to provide waqf in the form of CWLS. In connection with all that has been mentioned above, the author is interested in examining CWLS in the perspective of Islamic law and positive law in Indonesia, as the question arises: "Is Cash Waqf Linked Sukuk (CWLS) Less Than Ideal According to Islamic Laws?"

\section{Literature Review}

\subsection{Definition of Waqf}

The word waqf derives from the Arabic waqafa, yaqifu, waqfan which means to hold back, to stop, to stay in place, or to stay standing. The word shares the same meaning as habasa-yahbisuhabsan, while in the Arabic dictionary al-Mausū'ah al-'Arabiyah, waqf is defined as holding onto property and using its benefits for other good purposes. In addition, there are also those who interpret that waqf from the Arabic word "waqf" (jama' 'awqāf) which can be freely translated as "religious endowment" which implies piety to be used for the public interest in the way of Allah (Wahyuningsih et al., 2019; Anggraeni et al., 2020).

Waqf means a foundation founded based on the religion of Islam, such as a charity hall and is also defined as goods intended for public purposes, especially as endowments or for purposes related to religion such as to build mosques and the likes (Hamber \& Haneef, 2017; Seprillina et al., 2020). In the Islamic Encyclopedia, waqf is defined as stopping the transfer of ownership of a useful and durable asset by handing over the property to the manager, either individual, family or institution to be used for the public interest in the way of Allah.

The scholars of figh define the term waqf as follows (Kamal et al., 2019; Syarief, 2021; Sulistiani, 2021): a) According to Abu Hanifah, waqf is holding an object in order to use its benefits for righteousness, while the ownership of the object according to the law remains to the waqif. As a consequence, the property cannot be separated from the wāqif. The waqif is justified in withdrawing it and selling it and if the wāqif dies, the property becomes an inheritance for their heirs. This thought views waqf is only "contributing its benefits". b) Waqf according to the Malikiyah school is to make the benefits of an asset that is owned (or leased) to be given to people who are entitled to a contract within a certain period of time in accordance with the wishes of the waqif. c) The Shafi'i School and Ahmad bin Hanbal suggested that waqf is releasing the waqf property from the waqif's ownership. As a result of the law, waqif is prohibited from taking legal action against the waqf goods, such as selling or exchanging them. If Waqif dies, the waqf property cannot be inherited by the heirs and the Nazhir continues to distribute the benefits of the waqf goods to "Mauqūf "Alaih" (who is given a waqf) as binding alms. Therefore, the Shafi'i school defines waqf as not taking an action on an object that has the status of belonging to Allah, by donating its benefits to a virtue (social). 
The definition of waqf according to the Shafi'i School and Ahmad bin Hambal is followed by several other scholars, such as Imam al-Sayd Sabiq who argued that Waqf according to the shara' term, is to hold back the original object and use the fruit (the result), or to hold on to wealth and distribute its benefits in the way of Allah"), while Jabil al-Jazairi added that by holding, the property is not allowed to be sold, and to be endowed to other parties other than the mawquf. At the time of the Prophet, a well belonging to Uthman bin Affan was used by him and the people who needed it. Umar bin Khattab also endowed a land in Khaibar, the proceeds of which were given to the poor, relatives, to free slaves and for travelers. The two types of property no longer belonged to Uthman and Umar, so they could not be transferred or passed on to their descendants (Oubdi \& Raghibi, 2018).

From the several meanings of waqf that have been mentioned, the principal purpose of waqf is in the context of carrying out social worship as ordered by religion. The difference lies in the ownership of the goods or property after the waqf. Some scholars argued that the ownership remains with the Waqif, while other scholars argued that the property is turned to Allah. Regardless of the distinction, it is highly recommended that every Muslim who has wealth or the ability donate some of their assets according to the conditions set by Islamic law (Abas \& Raji, 2020; Kamaruddin et al., 2018).

\subsection{Legal Basis of Waqf}

The main sources of waqf advice are the Qur'an and hadith. Although the Qur'an does not mention waqf explicitly as it does to zakat, there are several verses of the Qur'an that implicitly do about waqf, such as Surah-Baqarah 215, 254, 261-262 and 267 and Ali'Imrān 92 which meanings are as follows:

1) They ask about what they earn. The answer: "Whatever wealth you spend, let it be given to parents, relatives, orphans, the poor and those who are on the travel." Whatever good you do, Allah is The All-Knowing one

2) O you who believe, spend (in the way of Allah) some of the sustenance we have given you before the day comes when there will be no trading and no more intercession.

3) "Those who spend their wealth in the way of Allah, then they do not accompany what they spend by mentioning their gifts and by not hurting (the recipient's feelings), they get their reward with their Lord. There is no worry for them and they are not sad."

4) "O you who believe! Spend (in the way of Allah) some of the results of your good efforts, and part of what We bring out from the earth for you."

5) "You will never reach the (perfect) virtue, before you spend some of the wealth you love, and whatever you spend, then indeed Allah is The All-Knowing."

The scholars interpret the words "anfiqū" and "tunfiqūna" in the verses above as donations of wealth which they understand is a derivation (musytaq) of the word infāq (giving or distributing of income) contained in these four verses which mean "spend" (as an imperative) and "you spend" (Abubakar, 2019).

The interpretations of "anfiq" or "tunfiqūna" as a donation of wealth can be found in the books of tafsr, such as: Tafsral-Qur'anal-'Adhīm, by Ibn Kathir, Tafs alr al-Manār by Muhammad Rashid-SurahSurah, and also in the Tafsr al-Jalalayn. According to the narrations of Hakim, Turmudzi, and Ibn Majah, "the revelation of the letter al-Baqarah verse 267 was when the people of Ansar were nicknamed "Ashabal-Nakhl" (the owners of the date palm gardens). The nickname was mentioned because most of them often produce abundant dates, but they were people who did not do good deeds (alms) (Hakim, 2019).

According to Musthofa and Wicaksono (2020), the word "infaq" which signifies that the donation of wealth can be in the form of alms or 'amal Jariyah can be found in the hadith of the Prophet Muhammad narrated by Muslim from Abu Hurairah, namely: 
a. Hadith about charity Jariyah: Meaning: "From Abu Hurairah, the Messenger of Allah said: "When the son of Adam (human) dies, then his deeds are cut off, except for three things, sadaqah jariyah, useful knowledge, and a pious child who prays for their parents".

b. Hadith about the order of the Messenger of Allah to Umar Bin Khattab which means: "Ibn Umar said that Umar's friend obtained a plot of land in Khaibar, then he went to the Messenger of Allah to ask for guidance. Umar said: O Messenger of Allah, I got land in Khaibar, I have never ever got such good wealth, then what do you order to me? The Messenger of Allah replied, if you like, you hold the principal (land), and you give alms (the proceeds). Then Umar gave it as charity, that shall not be sold, be given away, and be inherited. Ibn Umar said: Umar gave it to the poor, relatives, slaves, sabilillah, ibn sabil and guests. And it is not forbidden for those who control the land (the administrator) to eat from the results in a good way or eat without intending to possess it".

In addition to the basis of the Qur'an and Hadith above, the scholars agreed to accept waqf as a charity that is prescribed in Islam. No one can deny and reject the practice of waqf in Islam because waqf has become a practice that has always been carried out and practiced by the companions of the Prophet and the Muslims since the early days of Islam until today.

\subsection{Pillars and Conditions of Waqf}

Waqf as a good deed prescribed by the religion requires pillars (rukun) and conditions. Pillars are the main element in the formation of a thing. There are two thoughts of scholars regarding the pillars of waqf. First is the Hanafi school of thought which states that the pillar of waqf is only one, namely "șighat". Sighat is a declaration of waqf, take for example by saying, "I endow this land to the poor forever." or simply by saying "I endow this land" without mentioning a specific purpose. Second, the opinion of the majority of scholars (Maliki, Shafi'i and Hanbali schools of thought) state that there are four pillars of waqf (Ambrose et al., 2015; Sulaiman \& Zakari, 2015).

1) Waqif i.e. people who do waqf

2) Mawquf i.e. goods or objects to be donated

3) Mauqūf 'alaih i.e. people who receive waqf and

4) Sighat i.e. declaration of waqf

It is a convention among the scholars that each element of the pillars has conditions that must be met. If one of them is not fulfilled then the waqf is said to be invalid according to sharia. Conditions are as follows.

\subsection{Conditions of Waqif}

According to al-Nawawi, there are two conditions for waqif, namely the validity of his words, and having the ability to give tabarru' (donations). However, some scholars of the Shafi'i school themselves such as Ibn Hajar al-Sharbini and others view that the second condition suffices, because that condition already covers the first condition. It should be made sure as waqf is donation that will be transferred for good without compensation in the future. As a consequence, the person who is eligible to wagf has to be a major (i.e., not underage), mentally sound, of his own free will, not forced, not mahjur 'alaih (under guardianship), independent, not slave, and not muflis (bankrupt) (Zaman et al, 2020; Qurrata et al., 2020).

\subsection{Conditions of Mawqūf (the wealth being donated)}

Scholars have different views regarding the conditions related to the type of the mawqüf. In a number of figh literatures, it is found that the scholars disagree in determining the conditions that must be met for a mawqūf. First, the Syafi'iyah scholars stipulate that one of the conditions that must be met in mawquf is baqa' 'ayniha (eternal). In addition, according to the Shafi'iyah scholars, waqf objects must also be dawāmal-intifā (durable). Therefore, mawqūf (waqf object) must be an 
object that is eternal or having the integrity even after its benefits are taken (Mohammad, 2018; Abd Rahman \& Awang, 2018).

From the description above, it can be inferred that according to the Syafi'iyah scholars, objects whose integrity is not guaranteed after being used and does not last long, such as money and food do not qualify as mawquf. Also, the basic principle of waqf rules in the Syafi'iyah concept is that waqf objects may not be donated or traded (lātuba'walātuhab) (Zulfikar \& Sasnifa, 2020).

Second, the Hanafi school of law requires that the object as waqf as follows: (1) The object is valuable according to the shara' and is an immovable object. (2) Specific. (3) Being Wāqif's legal property at the time of the contract and is not related to the rights of others. Third, the Maliki school of thought requires Mawquf as follows (I) Being owned and not associated with other people. (2) Certain and clear assets. (3) Being utilizable. Therefore, assets that are being used as collateral for debts and assets that are being rented by people should not be waqf. However, the Maliki school of law allows waqf of animal benefits for use and endowment of food, money and other immovable objects (Faisal, 2021).

\subsection{Conditions of Mauqūf'Alaih (the receiver of waqf)}

Scholars of the Shafi'i school divide Mauqūf' alaih into two groups: (1) Specific person or specific people (2) Non-specific groups, such as the poor, mosques, and others. It was agreed that Mauqf 'alaih must be in a right to own (ahliyah al tamalluk) 19 at the time of the contract. As for the recipient of a non-specific waqf, such as the poor, mosques and others, it is required that the recipient must be definite and the goal is for virtue and to get closer to Allah, not for immoral purposes, take for instance waqf to establish gambling facilities or other facilities that lead to the unlawful and misguidance (Rohman et al., 2020).

\subsection{Conditions of sighat (declaration of waqf)}

1. Sighat waqf must be definite, be it in the form of speech or writing. It can also be in the form of satire (kinayah). However, according to Hanbali scholars, sighat waqf in satire (kinayah) is invalid, unless these conditions are met: a) there is an intention of the owner of the property, b) there are indications that indicate waqf, $c$ ) it is accompanied by something that shows the law of waqf.

2. Sighat is not limited to a certain time.

3. Sighat must not imply conditions as waqf requires transfer of ownership at a time. As an instance of sighat, one may declare "I endow (waqf) my land at this moment"

In addition, there are certain things that must be fulfilled in order for waqf to be considered valid, namely: (I) Waqf is handed over permanently, according to the opinion of most of the Fiqh scholars, except for the Maliki and Shi'i schools. (2) Waqf may not be withdrawn, either by the endower or his heirs, (3) Waqf assets may not be transferred for purposes that are contrary to the virtue. (4). Each waqf property must be used in accordance with the original purpose of the waqf (Shalihah et al., 2020; Rohman et al., 2020).

\subsection{Cash Waqf}

As described above, the Syafi'iyah scholars stipulate that one of the conditions that must exist in mawqf is "baqa' 'ayniha" (eternal; the integrity of the object can be guaranteed after being used). Besides, according to the Shafi'iyah scholars, waqf objects must also be "dawāmal-intifā" (durable) (Seprillina et al., 2020). Therefore, mawqūf must be an object that has an eternal element or the integrity of the object can be guaranteed after being utilized. Shafi'iyah scholars argue that objects whose integrity is not guaranteed after being used and does not last long, such as money and food do not meet the requirements for objects that may be endowed. Also, another principle of waqf of the Shafi'iyah concept is that waqf objects cannot be donated or sold. (lātuba'walātuhab) (Al Hasan, 2017). 
On the other hand, there are also Imams or schools of thought who hold different insights from those of the Syafi'iyah (Ibrahima et al., 2020). For Hanafiyah scholars, dinars or dirhams (money) may be donated even though their integrity is not eternal after their use. This is because the permissibility of cash waqf here is seen as an exception on the basis of istihsānbial-'urf. In such case, dirhams or cash can be used as waqf objects even though the object is not eternal, with the consideration that it is widely practiced in society. This money waqf is termed "cash waqf", where funds are collected from various sources in various legal and lawful ways, then these funds are invested with a high level of security (i.e. as the principal value of the eternal funds is guaranteed from depreciation) and the funds are invested into productive funds through sharia guarantee institutions (Ghozali \& Putra, 2019).

From the description of the cash waqf practice above, there are two fundamentals in the cash waqf practice that must be taken into consideration, namely the security and integrity of the funds must be maintained. This constitutes an effort to perpetuate the eternal value of the money. Second, the investment of these funds must be kept productive and sustainable, so that the outcomes can be continuously distributed to the waqf target (mawqūf 'alayh) (Anwar, 2015).

The idea and practice of cash waqf was pioneered by Mannan (2018) through the establishment of a Social Investment Bank Limited (SIBL) institution in Bangladesh. The distribution of funds in the form of productive financing for the real sector is mobilized, by providing microfinance through a Collective Investment Contract mechanism such as sharia mutual funds collected in Cash Waqf Certificates to people in need.

Waqf money in Indonesia is still not yet well-developed, which is partly due to the unsatisfactory economic growth, where the benefits are felt only by a part of the upper middle class, which is arguably ironic given that the majority of Indonesian happen to be Muslim. Another factor might lie on the novel fatwa regarding the legality of cash waqf by the Indonesian Ulema Council (MUI), which was only issued on May 11, 2002 (Qurrata et al., 2020).

Apart from the potential benefits to the community and the legality of cash waqf from the Indonesian Ulema Council, the implementation of cash waqf has never increased significantly because the adherents of the Syafi'iyah school, namely the majority of Muslims in Indonesia, principally believe that the practice of cash waqf is invalid.

\subsection{Analysis of Legal Istinbath Used by Mui in Establishing Cash Waqf Law}

Prior to discussing CWLS, first thing first is to examine the legal principles used by MUI in determining the law of cash waqf. The discussion on religious fatwas tends to be related to ijtihād with all its instruments, considering that religious fatwas are issued to the public after meeting many conditions. In determining Islamic law, ijtihād methods are employed, some of which are ijma', qiyās, istihsan, al-maslahahal-mursalah, istislab, 'urf, and sad az-zari'ah, but at the same time still holding firmly to the teachings that the ultimate purpose of Islamic law (maqashidal-syari'ah) is to bring the general benefit (mashālih 'aammah) and eliminate mafsadat (Rahayu \& Agustianto, 2020).

In the MUI fatwa decision No. 2 of 2002, concerning cash waqf, it is explained that the legal provisions of cash waqf are permissible (jawāz). In addition, the MUI fatwa also emphasized several things related to the practice of cash waqf, namely:

1. Cash waqf may only be distributed and used for things that are permitted by syar'i (musarraf mubāh)

2. The principal value of cash waqf must be guaranteed for its sustainability, it may not be sold, donated, or inherited.

Cash waqf is a waqf carried out by a person, group of people, institutions or legal entities in the form of cash, or including securities (Shukor et al., 2017; Qurrata et al., 2020). The Jawaz law on cash waqf in the fatwa of the Indonesian Ulema Council is the result of a compromise of various schools of thought that seem contradictory, but somehow in the end they were brought together. It is narrated by Imam Bukhari, that Imam-Zuhr gave his fatwa that waqf with dinars and dirhams is allowed to be 
used as a means of development, preaching, social and education for Muslims. The way to do this is to make the money as business capital then distribute the profits as waqf. The second opinion that is used as a reference for the MUI fatwa regarding cash waqf is the opinion of the Hanafi scholars who allow cash waqf as an exception on the basis of istihsānbial-'urf. In addition to the above opinions, another opinion used by the MUI is the opinion of some scholars in the Hanafi school of law, i.e., Abdullah bin Mas'ud who explains that, "what is considered good by Muslims is good in God's view, and what is considered bad by Muslims is bad in God's view."

According to some opinions of the scholars of the Shafi'i school based on the history of Abu Tsaur, Imam Shafi'i allowed waqf with dinars and dirhams because both are made of gold and silver which have durable properties, so they can be used as objects of waqf. The Hanafi scholars interpret waqf as holding back material objects (al-'ain) and giving charity to those for benevolent purposes. It signifies that the position of waqf property is still retained in the hands of the waqif. Thus, the waqif is still the owner of the property in his waqf, so that the endowment only occurs for the benefits of the property, not including the assets. Thus, according to Abu Hanifa, the nature of waqf is not permanent so it can be canceled at any time, or canceled due to death so that it becomes an inheritance. Therefore, in Abu Hanifah's view, waqf is more analogous to ijarah (lease), in which ownership does not change and remains the property of the waqif (Mauluddin \& Ab Rahman, 2018).

The opinion of Hanafiyah scholars who allow cash waqf on the basis of istihsānbi al-'urf is a method of determining the law on the basis of rejecting harm. Rejecting harm in the concept of mașlahah is a syara' goal that must be done. Hanafiyah scholars accept maslahah as a proposition in establishing the law, on the condition that the benefit exists and is supported by texts and ijma'. The application of the concept of maṣlahah among Hanafi scholars is known as the istihsān method (Ahmad, 2015).

The fatwa decision on cash waqf by the MUI took the opinion of Imam az-Zuhr and the Hanafi school of thought which made the maqāṣidal-syārî'ah aspect leading to mașlahah mursalah. MUI considers that cash waqf has great flexibility and benefits that other objects do not have and is a solution to society who long for a new form of waqf that is in accordance with current conditions.

\subsection{Cash Waqf Linked Sukuk (CWLS)}

Cash Waqf Linked Sukuk are cash waqf investments in State Sharia Securities (SBSN) or sukuk whose rewards are distributed by Nazhir (fund manager and waqf activities) to finance social programs and economic empowerment of the people. Thus, in fact CWLS is an innovation of cash waqf that has been around for quite some time. State Sharia Securities (SBSN) or known as Sukuk is one of the investment instruments issued by Islamic issuer institutions. The word Sukuk derives from Arabic, namely sakk which means document or certificate (Rahayu \& Agustianto, 2020).

The definition of sukuk based on the MUI fatwa No. 32/DSN-MUI/IX/2002 is a long-term security based on sharia principles issued by a legal entity established to carry out issuance activities (issuers) to sharia bond holders which oblige issuers to pay income to sharia bond holders in the form of ujrah (rent), profit sharing, or other forms of payment in accordance with the contract used, as well as repaying bond funds when they due.

Sukuk recognize proportional ownership of an asset over part (حصة) of SBSN assets in the form of SBSN financing objects and/or State-Owned Goods (BMN) that have economic value, in the form of land and buildings, as well as other than land and buildings which are used as the basis for SBSN issuance, as well as guarantees cash flows in the future in a certain period. The Accounting and Auditing Organization for Islamic Financial Institutions (AAOFI) No. 17 concerning Investment Sukuk defines sukuk as a certificate that has the same value as undistributed proof of ownership of an asset, benefit rights, and services or ownership of a particular investment project or activity (Kamla \& Haque, 2019).

Sukuk has also been regulated in Law No. 19 of 2008 concerning State Sharia Securities. In both regulations it is explained that sukuk issued must be based on sharia principles and in rupiah 
currency. Legal basis on sukuk come from the Qur'an, Hadith, and ljma' of the Ulama. Some of the suras in the Qur'an related to this are as follows:

1. QS. al-Nisa' [4]: 29: "O you who believe! Do not consume each other's wealth illicitly, but trade by mutual consent."

2. Q.S.Al-Baqarah 275: “...While Allah has justified trade and abode usury...” The development of sukuk is expected to suppress usury-based transactions by promoting profit-sharing transactions.

3. Q.S.Al-Baqarah 282: "O you who have believed, when you contract (i.e. when you have or contract a debt) a debt one upon another for a stated term, then write it down. And let a writer write it down between you with justice, and let not any writer refuse to write it down, as Allah has taught him."

4. QS. Al-Baqarah [2]: 278: "O you who believe! Have piety towards Allah and relinquish what remains from usury, if you are (true) believers."

5. QS. al-Ma-idah [5]: 1: "O you who believe! Meet the contracts ..."

Furthermore, the hadiths of the Prophet:

1. In the hadith Qudsi narrated by Abu Dawud, al-Daruquthi and al-Hakim from Abu Hurairah, the Messenger of Allah said: "Allah said: "I am the third party of two people who team as long as one party does not betray the other. If one of the parties has betrayed, I am out of them."

2. Hadith narrated by Ahmad, Abu Dawud, and Ad-Daraquthni from Sa'd Ibn Abi Waqqash (Abu Dawud's text), he said: "In the past we leased land and got paid with agricultural produce that grew on the edge of the ditch and grew in the part where the water flowed; so, the Messenger of Allah forbade us to do this and ordered us to rent it out for gold or silver."

3. Hadith of the Prophet narrated by Thabarani from Ibn Abbas: "Abbas bin Abdul Muthallib if he gives up property as a mudharabah (deposit), he requires his mudharib not to wade through the sea and not to go down the valley, and not to buy livestock. If these conditions are violated, he (mudharib) must bear the risk. What Abbas decreed was heard by the Messenger of Allah, and he confirmed it."

4. "Shulh (settlement of disputes through deliberation for consensus) can be carried out among Muslims, except for one which forbids what is lawful or makes lawful what is unlawful; and Muslims are bound by their terms except those that forbid what is lawful or make lawful what is unlawful."

In addition, the Indonesian National Sharia Council (DSN) allows sukuk activities based on the following figh rules: "The original law of muamalah is permissible unless there are arguments that forbid it" and another other fiqh rule that states: "The actions of the Imam [the authority holder] towards the people must follow the maslahat." (Lateh, 2016).

Another basis that DSN-MUI also pays attention to is the opinion of the ulama on government policies; among others, that "Imams (heads of state, authority holders) may carry out policies on state assets for matters which they consider to be beneficial for them (citizens); Among these benefits is selling some of the wealth of the Baitul Mal (state treasury) in order to raise sufficient funds to finance their general welfare and needs. This is considering that the Imam's policy, if it is based on the benefits related to public affairs, is considered invalid according to Sharia law unless it is in accordance with the maslahah; if it is in accordance with the maslahah then the policy is valid."

Cash Waqf Linked Sukuk (CWLS) are sharia bonds or sukuk based on cash waqf, where the collected funds are invested in state sukuk in order to assist fiscal financing in social contexts, such as in the fields of education, health, and development. The objectives of the development of Cash Waqf Linked Sukuk (CWLS) are strengthening the capacity of the Islamic financial economy to make it easier for people to make safe and productive cash waqf, institutional strengthening of national waqf management, supporting the development of social investment funds (amidst COVID-19 pandemic) and productive waqf in Indonesia, supporting the National Waqf Movement, strengthening the waqf ecosystem in Indonesia and encouraging inclusive and sustainable economic growth. Furthermore, the issuance of Law No. 41 of 2004 concerning Waqf and Law No. 19 of 2008 concerning State Sharia 
Securities (SBSN) is expected to become the legal basis for Cash Waqf Linked Sukuk (CWLS). Referring to the DSN-MUI Fatwa No. 131/DSN-MUI/X/2019 Waqf Sukuk are sukuk issued in order to optimize the benefits of waqf assets and/or yields for the public interest (mashalih 'ammah) that do not conflict with sharia principles (Faudji \& Paul, 2020; Rahayu \& Agustianto, 2020).

Waqf sukuk also acted as the impetus for the issuance of CWLS which is based on sharia principles with several provisions in its implementation. Its contracts can be lease-based transactions (ijarah), i.e., based on mudharabah and musyarakah cooperation. It can also be in the form of buying and selling, namely murabahah, salaam, and istishna' related to the MUI fatwa with regard to the substance of each contract. Cash Waqf Linked Sukuk have several advantages as the proceeds from the investment of waqf sukuk will be used for the formation of new waqf assets and financing social activities. The Indonesian Waqf Board is also exempted from taxation so that investment returns are obtained competitively (Sasongko, 2021).

However, an analysis of the mechanism for implementing CashWaqf-Linked Sukuk in practice still needs to be done to ensure its compliance with the pillars of waqf and other Sharia provisions such as not containing usury, gharar and hybrid contracts which are still being disputed. The mechanism of CWLS and Retail CWLS is as follows (Sasongko, 2021; Nurhayati, 2021).

1. Waqif donate (waqf) money to nazhir the desired amount (at least one million rupiah) through nazhir partners for a certain period of time (two years) or forever.

2. Waqif deposit the money waqf funds into the account of Nazhir's partner in LKS-PWU.

3. Waqif performs Waqf Pledge in front of LKS-PWU/bank officials who are appointed as Makers of Waqf Pledge Deed (PPAIW).

4. Deposits of waqf funds from waqif will be placed in the wadiah checking account in the name of the Nazhir partner before being placed into the Nazhir/BWI account.

5. If a cumulative total of 50 billion rupiah has been collected from all Nazhir partners, then BWI can transfer it to the BWI account at LKS PWU as wadiah.

6. Then the funds that have been raised are used to buy SBSN which has been issued by the Ministry of Finance within a certain period of time.

7. The Ministry of Finance pays SBSN coupons to Nazhir BWI in accordance with the contract agreed at the beginning of the agreement.

8. Coupons that have been paid are reduced by $10 \%$ by nazhir as a management fee and then channeled through nazhir partners to finance the development of waqf assets or public facilities.

9. The Ministry of Finance returns the cash waqf funds to BWI after the SBSN or State Sukuk are due.

10. BWI gives orders to partners nazhir and LKS-PWU to refund waqf money for a certain period of time to waqif.

11. Payment of cash waqf funds to waqif through operational banks that have been appointed by BWI.

\section{Methodology}

This paper adopted a qualitative method using library research approach. The fundamental rationale is that the library research can be used to understand the current phenomenon. The data in this study were collected from various literature and primary sources including Holy Quran, Sunnah, published papers and books. In this study, we followed several stages including gathering materials, reading references and providing notes, analyzing the research notes. This research also interviewed to Islamic figures in Indonesia. The discussion put forward is based on the materials studied through the arguments of the Qur'an and Sunnah, books of figh and interpretation. From these books, various opinions and arguments of the scholars along with the arguments they put forward are quoted, then a conclusion is drawn. 


\section{Results and Discussion}

CWLS is a cash waqf that is invested through stated sukuk which is safe and free of default risk which aims to support the growth of the sharia financial market in Indonesia. The Ministry of Religious Affairs and the Indonesian Waqf Board act as supervisors in conducting the Cash Waqf Linked Sukuk program.

Based on the mechanism for implementing Cash Waqf Linked Sukuk (CWLS), it is evident that CWLS has fulfilled the pillars of waqf, namely the presence of a person who is waqf (waqif), waqf object (mawqūf), waqf recipient (mawqūf'alaih), sighat (waqf pledge), payment of waqf assets and returns waqf principal at maturity. Meanwhile, whether the payment is in the form of ujrah (rent), profit sharing, or other forms of payment in accordance with the contract used, it does not violate Sharia principles because it is associated with SBSN assets in the form of SBSN financing objects or State Property (BMN) which have an economic value, in the form of land and buildings, as well as other than land and buildings as the basis for issuing SBSN. This is in line with the MUI Fatwa Number 1 of 2004 concerning Bank Interest, but with a note that the determination of the margin of 0.5 percent/year still needs to be reviewed for compliance with sharia provisions considering that dynamics in a business is a certainty (except in ijarah transactions), while the CWLS margin is based on time, calculated with certainty in advance, and based on percentage. This finding is an agreement with some preliminary studies by Qurrata et al. (2020); Nurhayati (2021); Sasongko (2021).

Another problem that needs to be further studied is its compliance with Sharia related to the existence of two or more transactions in one contract in the CWLS, starting from the delivery of waqf money, buying SBSN with a murabahah contract, salam or other contracts, all of which are hybrid contracts. According to Nazih Hammad, multi contract is an agreement between two parties to carry out a contract containing two or more contracts, such as buying and selling with leases, grants, wakalah, qardh, sahraf (currency exchange), syirkah, and mudharabah. Therefore, that all the legal consequences of the collected contracts, as well as all the rights and obligations that arise are seen as a single entity that cannot be separated, as are the legal consequences of one contract. According to Ibn Qayyim that the Prophet forbade multi-contracts between salaf contracts (giving loans/qardh) and buying and selling, even though the two contracts are legally permissible if they apply separately. Likewise, most Islamic economic literature in Indonesia pertains that multi contracts are prohibited by sharia. Regardless being viewed to no longer be able to respond to contemporary financial transactions, solutions must be found about these multi contract issues. The hybrid contract method should be the flagship in product development (Rahayu \& Agustianto, 2020).

Cash Waqf Linked Sukuk (CWLS) have an immensely positive impact on sustainable economic development (Fauziah et al., 2021; Lailatullailia et al., 2021). Therefore, this investment instrument is suitable to be applied in Indonesia given the huge potential of waqf assets to be productive in line with the Islamic economic system which is based on sharia principles.

\section{Conclusion}

Based on the discussion, conclusions are drawn as follows: first, the mechanism of implementations of the Cash Waqf Linked Sukuk (CWLS) has fulfilled the pillars of waqf, namely the presence of a person who is waqf (waqif), the object being donated (mawqūf), the recipient of the waqf (mawqūf 'alaih), sighat (declaration of waqf), payment of waqf proceeds, and repayment when due. Second, the determination of the margin of 0.5 percent/year still needs to be reviewed for compliance with the sharia provisions considering that fluctuations in a business is a certainty (except in ijarah transactions), while the CWLS margin is based on time, calculated with certainty in advance, and is based on a percentage. Third, it is necessary to further examine its compliance with Sharia as there are hybrid contracts in CWLS, such as when handing the cash, buying sukuk in murabahah contract, salaam and other contracts which according to economic literature Sharia in Indonesia is prohibited. Lastly, CWLS provides enormous benefits for sustainable economic development. Therefore, the support of all Muslim communities, especially scholars and community 
leaders, is very much needed, both for its development and supervision so that it is in accordance with the objectives and principles of Sharia. The study is limited by the lack of information on implementation cash waqf from other Islamic countries and it is suggested to incorporate different demographic setting that can be used to reach a deeper understanding for this concern.

\section{References}

1. Abas, F. N., \& Raji, F. (2018). Factors contributing to inefficient management and maintenance of waqf properties: A literature review. International Journal of Islamic and Civilization Studies, 5(3), 53-67.

2. Abbasi, R., Miri, M., \& Hasanvand, M. (2019). Recognize the policy pattern in the waqf entity to develop general models of promotion and dissemination of policies. Scientific Journal of Islamic Management, 27(3), 49-82.

3. Abd Rahman, A. A., \& Awang, A. B. (2018). Exploring the dynamics of cash waqf: a critical analysis of its implementation in Malaysia. Intellectual Discourse, 1109-1128.

4. Abubakar, M. (2019). Waqf philanthropy and orphans' socio-economic development in Northern Nigeria based on Maqasid al Shariah principles. In Revitalization of Waqf for Socio-Economic Development, Volume I (pp. 31-42). Palgrave Macmillan, Cham.

5. Ahmad, M. (2015). Cash waqf: historical evolution, nature and role as an alternative to riba-based financing for the grass root. Journal of Islamic Finance, 176(3160), 1-12.

6. Al Hasan, F. A. (2017). Waqf management in Indonesia through asset based community development $(\mathrm{ABCD})$ Approach. International Journal of Social Science and Economic Research, 2(8), 4070-87.

7. Ambrose, A. H. A. A., Aslam, M., \& Hanafi, H. (2015). The possible role of waqf in ensuring a sustainable Malaysian federal government debt. procedia economics and finance, 31, 333-345.

8. Anggraeni, R. D., Yunus, N. R., \& Rezki, A. (2020). Legal policies for implementing waqaf online in Indonesia. Mizan: Journal of Islamic Law, 4(1), 83-92.

9. Anggraini, J., Panorama, M., \& Handayani, D. (2019). Analysis of the impact of digitization of Islamic banking for Small and Medium Enterprises (SMEs) in Indonesia. Journal of International Conference Proceedings, 2(1). Doi: 10.32535/jicp.v2i1.448

10.Anwar, T. (2015). Islamic gift economy vis-à-vis waqf (endowment) as vehicles for social entrepreneurship. International Journal of Pluralism and Economics Education, 6(4), 386-408.

11.Faisal, F. (2021). The Use of Cash Waqf Funds and Its Various Legal Problems in Indonesia. International Journal Reglement \& Society (IJRS), 2(2), 111-118.

12.Fatwa MUI No. 2 of 2002 concerning cash waqf. Retrieved from https://dsnmui.or.id/kategori/fatwa/

13.Fatwa No. MUI No. 131/DSN-MUI/X/2019 on Waqf. Retrieved from https://dsnmui.or.id/kategori/fatwa/

14.Faudji, R., \& Paul, W. (2020). Cash waqf linked sukuk dalam optimalkan pengelolaan wakaf benda bergerak (uang). Jurnal IImiah MEA (Manajemen, Ekonomi, \& Akuntansi), 4(2), 331-348.

15.Fauziah, N. N., Ali, E. R. A. E., \& Bacha, A. M. (2021). An analysis of cash waqf linked Sukuk for socially impactful sustainable projects in Indonesia. Journal of Islamic Finance, 10, 001-010.

16.Ghazali, N. A., Raji, F., \& Mohammad, M. T. S. H. (2019). Issues on Waqf land registration process in Malaysia and improvement proposals. UMRAN-International Journal of Islamic and Civilizational Studies, 6(3), 57-71.

17.Ghozali, M., \& Putra, Y. S. (2019). The management of cash waqf on dinar and dirham from the view of islamic law (Case study at Wakala Parent Bintan). Al-Iktisab: Journal of Islamic Economic Law, 3(2). 
18. Hakim, L. (2019). Studi Hadis "Birrul Walidain": Hadis Sunan Ibn Majah No Indeks 3664 Perspektif Muhammad Nashiruddin Al-Albani (Doctoral dissertation, UIN Sunan Ampel Surabaya).

19. Hamber, N., \& Haneef, M. (2017). Waqf-based social micro venture fund: A proposal for the Malay-muslim community in Singapore. Journal of King Abdul-Aziz University: Islamic Economics, 30(1), 37-60.

20.Ibrahima, D., Zainuria, A., \& Hudab, M. (2020). Empowering wakaf (Islamic endowment) for economic development: An Insightful value of Nazir Waqf in Indonesia. UMRAN-International Journal of Islamic and Civilizational Studies, 7(1), 103-114.

21.Iman, N., Santoso, A., \& Kurniawan, E. (2020). Online based waqf management system in Indonesia: A new model in management of waqf administration. International Journal of Innovation, Creativity and Chang, 10(11), 164-180.

22.Indra, S., \& Hakim, M. L. (2020). Pemberdayagunaan imbal hasil wakaf uang melalui Sukuk: regulasi, implementasi, dan modelnya untuk pemberdayagunaan usaha mikro, kecil, dan menengah Di Indonesia. Sosio Informa, 6(3), 264-279.

23.Kamal, M., Hanafiyah, H., Nainunis, N., Safrizal, S., Munawir, M., \& Bahri, S. (2019). Method of Instinbāth Law of Money Waqf Abu Hanifah immediate perspective. Budapest International Research and Critics Institute-Journal (BIRCI-Journal), 2(1), 304-313.

24.Kamaruddin, M. I. H., Masruki, R., \& Hanefah, M. M. (2018). Waqf Management Practices: Case Study in a Malaysian Waqf Institution. World Journal of Social Sciences, 8(3), 1-12.

25.Kamla, R., \& Haque, F. (2019). Islamic accounting, neo-imperialism and identity staging: The Accounting and Auditing Organization for Islamic Financial Institutions. Critical Perspectives on Accounting, 63, 102000.

26.Lailatullailia, D., Setiyowati, A., \& Wahab, A. (2021). Peran Bank Syariah sebagai mitra Nazhir dalam pengelolaan produk investasi CWLS Ritel SWR001 dalam perspektif prinsip-prinsip pokok wakaf (The Role of Sharia Banks as Nazhir Partners in the Management of CWLS Retail SWR001 Investment Products). Perisai: Islamic Banking and Finance Journal, 5(1), 95-95.

27.Lateh, B. (2016). Multiple contracts according to the fatwa of national sharia council. International Journal of Nusantara Islam, 4(1), 41-48.

28.Latief, N. F. (2019). Accounting for zakat and infaq (Sadaqah) at Badan Amil Zakat Nasional (BAZNAS) in North Sulawesi, Indonesia. International Journal of Accounting \& Finance in Asia Pasific (IJAFAP), 2(2), 1-9.

29.Law no. 19 of 2008 concerning State Sharia Securities (SBSN). Retrieved from https://dsnmui.or.id/kategori/fatwa/

30.Law No. 19 of 2008 concerning state sharia securities. Retrieved from https://dsnmui.or.id/kategori/fatwa/

31.Law no. 41 of 2004 concerning Waqf. Retrieved from https://dsnmui.or.id/kategori/fatwa/

32.Mannan, M. A. (2018). Linking Islamic commercial and social finance with special reference to cash-waqf as new strategy of interest-free micro-credit for family empowerment of the poor towards establishing world social bank: A case study approach. Journal of Islamic Monetary Economics and Finance, 3(Special Issue), 1-24.

33.Mauluddin, M. I., \& Ab Rahman, A. (2018). Cash waqf from the perspective of majelis ulama indonesia (MUI) and the scholars of Aceh. In New Developments in Islamic Economics. Emerald Publishing Limited.

34.Merlinda, S., Qurrata, V. A., Yusida, E., Purnamasari, V., Seprillina, L., \& Hussain, N. E. (2021). The role of cash waqf as a source of micro business financing for strengthening the local economy: A case study in Gunung Kawi District, Malang Regency. Review of Integrative Business and Economics Research, 10, 136-144. 
35.Ministry of Finance. (2020). Amandment of state budget posture 2020. Retrieved from https://www.djppr.kemenkeu.go.id/

36.Mohammad, M. T. S. H. (2018). Maqāșid al-Sharī’ah and waqf: Their effect on waqf law and economy. Intellectual Discourse, 1065-1091.

37.Musthofa, A. H., \& Wicaksono, A. K. (2020). Efektifitas regulasi \& pengelolaan infaq, sedekah dan dana sosial keagamaan. Jurnal At-Tamwil: Kajian Ekonomi Syariah, 2(1), 23-50.

38.Nezliani, L. (2021, March). Analisis peran Bank Umum Syariah sebagai potential investor untuk mengoptimalkan cash wakaf Link Sukuk. Annual Conference of Ihtifaz: Islamic Economics, Finance, and Banking, 203-218.

39. Nurhayati, S. (2021). Sharia cooperatives' productive waqf management model through financial technology services in bandung city area to promote the people's economy. International Journal of Science, Technology \& Management, 2(1), 272-280.

40.Oubdi, L., \& Raghibi, A. (2018). Sukuk-Waqf: The Islamic solution for public finance deficits. European Journal of Islamic Finance, 9, 1-7.

41.Prananingtyas, P., \& Disemadi, H. S. (2020). Legal consequences of dualism regulations on micro waqf bank as a sharia microfinance institutions in Indonesia. Varia Justicia, 16(1), 1-14.

42.Qurrata, V. A., Seprillina, L., Narmaditya, B. S., \& Hussain, N. E. (2020). Media promotion, Islamic religiosity and Muslim community perception towards charitable giving of cash waqf. International Journal of Monetary Economics and Finance, 13(3), 296-305.

43.Rahayu, R. D., \& Agustianto, M. A. (2020). Analisis implementasi Cash Waqf Linked Sukuk (CWLS) perspektif prinsip ekonomi syariah. Management of Zakat and Waqf Journal (MAZAWA), 1(2), 145-161.

44.Rahmansyah, W. (2021). Pengakuan aset wakaf oleh wakif perusahaan dalam produk Cash Wakaf Linked Sukuk (Sinkronisasi Laporan Keuangan Nadzhir Dan Wakif Dalam PSAK 112). El-Wasathiya: Jurnal Studi Agama, 9(1), 94-107.

45.Rohman, A., Hisyam, M. A., Muhtadi, R., \& Arifin, N. R. (2020, May). Construction of waqf istibdal regulations for empowering non productive waqf in Indonesia. In Riau Annual Meeting on Law and Social Sciences (RAMLAS 2019) (pp. 134-137). Atlantis Press.

46.Sasongko, F. N. (2021). Cash waqf linked sukuk: potensi dan tantangan. Indonesian Interdisciplinary Journal of Sharia Economics (IIJSE), 4(1), 190-200.

47.Seprillina, L., Qurrata, V. A., Narmaditya, B. S., \& Hussain, N. E. B. (2020). The effectiveness productive waqf as a social welfare development through community empowering: A case in Islamic Hospital Foundation Malang. Review of Integrative Business and Economics Research, 9, 67-74.

48.Shalihah, M. A., \& Cahyo, E. N. (2020). Cash Waqf Auction for the establishment of Islamic institution on the perspective of islamic law and positive law (A case study on Trensains Islamic Institution, Sragen, 2018-2019). Al-Iktisab: Journal of Islamic Economic Law, 4(1), 69.

49.Sulaiman, M., \& Zakari, M. A. (2015). Efficiency and effectiveness of waqf institutions in Malaysia: toward financial sustainability. Access to finance and human development-essays on zakah, awqaf and microfinance, 43, 2357-1330.

50.Sulistiani, S. L. (2021). The legal position of waqf for non-muslims in efforts to increase waqf assets in Indonesia. Samarah: Jurnal Hukum Keluarga dan Hukum Islam, 5(1), 357-371.

51.Syarief, E. (2021). Optimization of waqf land management in Indonesia. International Journal of Research in Business and Social Science, 10(2), 270-283.

52.Wahyuningsih, G., Putri, C. W., \& Nugroho, M. R. B. B. (2019, November). Operational strategy and business management system at Sofyan Inn Hotel Unisi Yogyakarta. In ASEAN/Asian Academic Society International Conference Proceeding Series (pp. 62-66). 
53.Yasin, R. M. (2021). Cash Waqf Linked Sukuk: Issues, challenges and future direction in Indonesia. Journal Of Islamic Economics and Business, 7(1), 100-112.

54.Yunita, P. (2020). Cash Waqf Linked Sukuk (CWLS) Model: For Indonesia sustainable food security. Al-Awqaf: Jurnal Wakaf dan Ekonomi Islam, 13(1), 59-72.

55.Zaman, I., Ullah, S., \& Afaq, A. (2020). Waqf of intellectual property: A critical review of contemporary literature. Journal of Religious Studies, 3(2), 17-41.

56.Zatadini, N., Marjany, N., \& Syamsuri, S. (2019, December). Risk mitigation strategy in Islamic crowdfunding institution (Case study at Islamic crowdfunding institution in Indonesia). Journal of International Conference Proceedings, 2(3), 170-175.

57.Zulfikar, A. A., \& Sasnifa, P. (2020). Transaction in non-cash payments through Ovo application: an Islamic judgment study by the Mazhab Syafi'i. Ulul Albab: Jurnal Studi dan Penelitian Hukum Islam, 3(2), 219-230. 